J. Clin. Chem. Clin. Biochem.

Vol. 18, 1980, pp. 327-332

\title{
Evaluation of an Enzyme-Immuno-Assay for the Determination of Total Serum Estrogens in Pregnancy
}

\author{
By A. Lanser ${ }^{1}$ ), B. G. Blijenberg, H. C. S. Wallenburg and B. Leijnse \\ Department of Clinical Chemistry; Department of Obstetrics and Gynecology University Hospital and Department \\ of Chemical Pathology Erasmus University Rotterdam
}

(Received September 20, 1979/January 3, 1980)

Summary: We have evaluated a new diagnostic kit for the determination of total estrogens in serum or plasma of pregnant women by means of an enzyme-immuno-assay.

Within-run precision had a coefficient of variation of $4.7-4.9 \%$ for total estrogen concentrations of 400 to $2000 \mathrm{nmol} / 1$. For the same range of concentrations, day-to-day precision was found to be $5.9-8.9 \%$. Mean analytic recovery of unconjugated estriol was $102 \%$. Enzymatic hydrolysis of different estrogen conjugates was shown to be virtually complete. The antiserum used in the assay has the same affinity for estrone, estradiol and estriol.

Preliminary clinical studies included 14 pregnant women. The results suggest that the determination of total estrogens in pregnancy plasma can be used to monitor fetoplacental function in much the same way as urine total estrogens are used.

\section{Evaluation eines Enzymimmunoassay zur Bestimmung der Gesamt-Östrogene im Serum während der Schwangerschaft}

Zusammenfassung: Ein neues Testbesteck für die Bestimmung der Gesamt-Östrogene in Serum oder Plasma schwangerer Frauen mittels Enzymimmunassay wird bewertet. Für Gesamt-Östrogen-Konzentrationen von 400 bis $2000 \mathrm{nmol} / 1$ wurde für die Präzision in der Serie ein Variationskoeffizient von 4,7-4,9\% gefunden, für die Präzision von Tag zu Tag von 5,9-8,9\%. Unkonjugiertes Östriol wurde zu $102 \%$ wiedergefunden. Die enzymatische Hydrolyse verschiedener Östrogenkonjugate war offenbar vollständig. Das benutzte Antiserum hat gleiche Affinitäten für Östron, Östradiol und Östriol.

Vorläufige klinịsche Studien umfaßten 14 Schwangere. Die Ergebnisse weisen darauf hin, daß die Bestimmung der Gesamt-Östrogene im Plasma Schwangerer in gleicher Weise wie die im Harn zur Überwachung der fetoplacentalen Funktion angewandt werden kann.

\section{Introduction}

It is generally agreed that determination of estrogens is of clinical value in monitoring fetoplacental function. Most laboratories measure tọtal estrogen excretion in 24-hour urine samples.

With the introduction of protein binding methods (1, $2,3)$ accurate measurement of the low estrogen concentrations in serum or plasma has become possible. At present, several rạdio-immuno-asșay kits for the measurement of estrogens in pregnancy serum or plasma, instead of urine, are commercially available. Recently, a new commercial kit (Estronosticon ${ }^{\circledR}$ ) based on the work of Bosch et al. (4), has become available.

With this kit, total estrogens in serum are determined by means of an enzyme-immuno-assay principle.
Free estrogen in a hydrolyzed, diluted serum sample is allowed to compete with an estriol-enzyme conjugate for a limited amount of anti-estrogen serum. After incubation, the antibody is precipitated with a second antibody, coupled to cellulose $\left(\mathrm{DASP}^{\circledR}\right)$ and the enzymatic activity is measured in the precipitated, bound fraction. The coupled enzyme used in the test is horse-radish peroxidase (EC 1.11.1.7). Estrogen concentrations are read from a calibration curve, obtained with a manufacturer-supplied estriol standard. In this study, we have evaluated this test with regard to precision, recovery, antibody affinity to different estrogens and practical and clinical usefulness as compared with our routine total estrogen determination in urine.

1) Present address: R. K. Hospital, Dept. of Clinical Chemistry, Houttuinen 10,3300 AL Dordrecht, The Netherlands. 


\section{Materials and Methods}

\section{Equipment}

All absorbance measurements were performed at $492 \mathrm{~nm}$ on a Beckman model 25 spectrophotometer. For pipetting serum samples, Helix pomatia extract and DASP ${ }^{\circledR}$ suspension we used Eppendorf pipets with Eppendorf disposable tips. For the addition of antiserum and conjugate we used a Hamilton PB 600 repeating dispenser, equipped with a $2.5 \mathrm{ml}$ syringe. All other solutions were pipetted either with Seripettors ${ }^{\circledR}$ (Labora Mannheim $\mathrm{GmbH}$, W. Germany) or normal volumetric pipets.

\section{Estrogens and estrogen conjugates}

All estrogens and estrogen conjugates used in the study were purchased from Sigma Chemical Company. Names, catalogue numbers and abbreviations that will be used in figure 2 and table 4 are given in table 1 .

Tab. 1. Estrogens and estrogen conjugates used in the study. The abbreviations are used in figure 2 and table 4 .

\begin{tabular}{|c|c|c|}
\hline Product name & $\begin{array}{l}\text { Catalogue } \\
\text { number }\end{array}$ & $\begin{array}{l}\text { Abbrevia- } \\
\text { tion }\end{array}$ \\
\hline 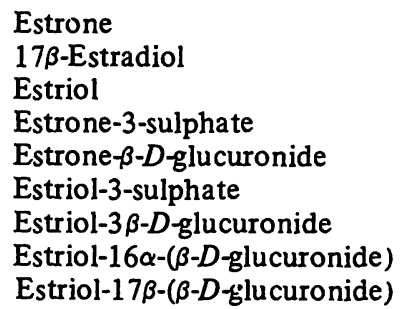 & $\begin{array}{l}\text { E } 9750 \\
\text { E } 8875 \\
\text { E } 1253 \\
\text { E } 0251 \\
\text { E } 1752 \\
\text { E } 6375 \\
\text { E } 2002 \\
\text { E } 1877 \\
\text { E } 6253\end{array}$ & $\begin{array}{l}E_{1} \\
E_{2} \\
E_{3} \\
E_{1}-3 S \\
E_{1}-3 G \\
E_{3}-3 S \\
E_{3}-3 G \\
E_{3}-16 G \\
E_{3}-17 G\end{array}$ \\
\hline
\end{tabular}

\section{Routine urine total estrogen determination}

The routine method which was used for urine total estrogen determinations was an Auto-Analyzer method, identical to the method described by Van Kessel et al. (5). This method is based on the Ittrich technique (6).

\section{Enzyme-immuno-assay for serum total estrogen determination}

The enzyme-immuno-assay (Estronosticon ${ }^{\circledR}$, Organon Technica B. V., Oss, The Netherlands) was performed according to the manufacturers' instructions. To reduce the reagent cost and the necessary sample volume ( $500 \mu \mathrm{l}$ of serum accord to the instruction manual) we reduced all volumes mentioned in the instruction manual by half. All samples were analyzed in duplicate.

\section{Manual estrogen determinations}

Stock solutions of estrogen conjugates, used in the hydrolysis experiments were analyzed for their real estrogen content by the method of Kreutzer \& Meulendijk (7), based on the Kober reaction.

\section{Creatinine determination}

Creatinine was determined by the method of the Dutch Standardization Committee on Clinical Chemistry.

\section{Results}

\section{Precision}

Six different sera from pregnant women were used for precision studies. Six different urine samples from pregnant women were used to compare the precisions of both methods. For day-to-day precision studies, the sera were analyzed 10 or 11 times in a period of about 2 weeks, and urines were analyzed 16 or 17 times within a period of about 2 months, during the studies, the samples were kept at $-20^{\circ} \mathrm{C}$ until needed. The results are given in table 2.

\section{Linearity}

Linearity is mainly dependent on the amount of conjugated estrogens that can be hydrolyzed by the Helix pomatia extract in one hour; after this step in the analysis procedure, the hydrolyzed sample is diluted until the estrogen concentration falls within the range of the calibration curve $(0.66-2.78 \mathrm{nmol} / \mathrm{l})$. The hydrolyzing capacities of the Helix pomatia extract will be discussed later.

A representative example of a standard curve is shown in figure 1 .

\section{Recovery}

To $1 \mathrm{ml}$ of 12 different serum samples from pregnant women $50 \mu \mathrm{l}$ of different stock estriol solutions were added. All serum samples supplied with extra estriol were allowed to equilibrate overnight and were analyzed

Tab. 2. Results of precision studies with human sera and urines. Serum samples were analyzed with the enzyme-immuno-assay, urine samples with the autoanalyzer method.

\begin{tabular}{|c|c|c|c|c|c|c|c|c|c|}
\hline \multirow{2}{*}{$\begin{array}{l}\text { Serum } \\
\text { sample } \\
\text { no. }\end{array}$} & \multicolumn{4}{|c|}{ Within-run precision } & \multirow{2}{*}{$\begin{array}{l}\text { Serum } \\
\text { sample } \\
\text { no. }\end{array}$} & \multicolumn{4}{|c|}{ Day-to-day precision } \\
\hline & $\begin{array}{l}\text { Average } \\
(\mathrm{nmol} / \mathrm{l})\end{array}$ & $\begin{array}{l}\text { S. D. } \\
\text { (nmol/l) }\end{array}$ & $\begin{array}{l}\text { C. V. } \\
(\%)\end{array}$ & $\mathbf{n}$ & & $\begin{array}{l}\text { Average } \\
\text { (nmol/l) }\end{array}$ & $\begin{array}{l}\text { S. D. } \\
\text { (nmol/1) }\end{array}$ & $\begin{array}{l}\text { C. V. } \\
\text { (\%) }\end{array}$ & $\mathbf{n}$ \\
\hline $\begin{array}{l}1 \\
2 \\
3\end{array}$ & $\begin{array}{r}420 \\
1310 \\
1910\end{array}$ & $\begin{array}{l}18.3 \\
67.1 \\
91.5\end{array}$ & $\begin{array}{l}4.7 \\
4.9 \\
4.9\end{array}$ & $\begin{array}{r}17 \\
\cdots \quad 17 \\
18\end{array}$ & $\begin{array}{l}4 \\
5 \\
6\end{array}$ & $\begin{array}{r}310 \\
1290 \\
2080\end{array}$ & $\begin{array}{r}18.2 \\
114.0 \\
176.8\end{array}$ & $\begin{array}{l}5.9 \\
8.9 \\
8.5\end{array}$ & $\begin{array}{l}11 \\
10 \\
10\end{array}$ \\
\hline \multirow{2}{*}{$\begin{array}{l}\text { Urine } \\
\text { sample } \\
\text { no. }\end{array}$} & \multicolumn{4}{|c|}{ Within-run precision } & Urine & \multicolumn{4}{|c|}{ Day-to-day precision } \\
\hline & $\begin{array}{l}\text { Average } \\
(\mu \mathrm{mol} / \mathrm{l})\end{array}$ & $\begin{array}{l}\text { S. D. } \\
(\mu \mathrm{mol} / 1)\end{array}$ & $\begin{array}{l}\text { C. V. } \\
(\%)\end{array}$ & $\mathrm{n}$ & $\begin{array}{l}\text { sample } \\
\text { no. }\end{array}$ & $\begin{array}{l}\text { Average } \\
(\mu \mathrm{mol} / \mathrm{l})\end{array}$ & $\begin{array}{l}\text { S. D. } \\
(\mu \mathrm{mol} / \mathrm{l})\end{array}$ & $\begin{array}{l}\text { C: V. } \\
(\%)\end{array}$ & $\mathbf{n}$ \\
\hline $\begin{array}{l}1 \\
2 \\
3\end{array}$ & $\begin{array}{r}36 \\
76 \\
127\end{array}$ & $\begin{array}{l}0.1 \\
2.6 \\
6.0\end{array}$ & $\begin{array}{l}2.7 \\
3.5 \\
4.7\end{array}$ & $\begin{array}{l}20 \\
10 \\
20\end{array}$ & $\begin{array}{l}4 \\
5 \\
6\end{array}$ & $\begin{array}{r}34 \\
72 \\
123\end{array}$ & $\begin{array}{r}4.9 \\
8.0 \\
12.0\end{array}$ & $\begin{array}{r}14.5 \\
11.1 \\
9.8\end{array}$ & $\begin{array}{l}16 \\
16 \\
17\end{array}$ \\
\hline
\end{tabular}




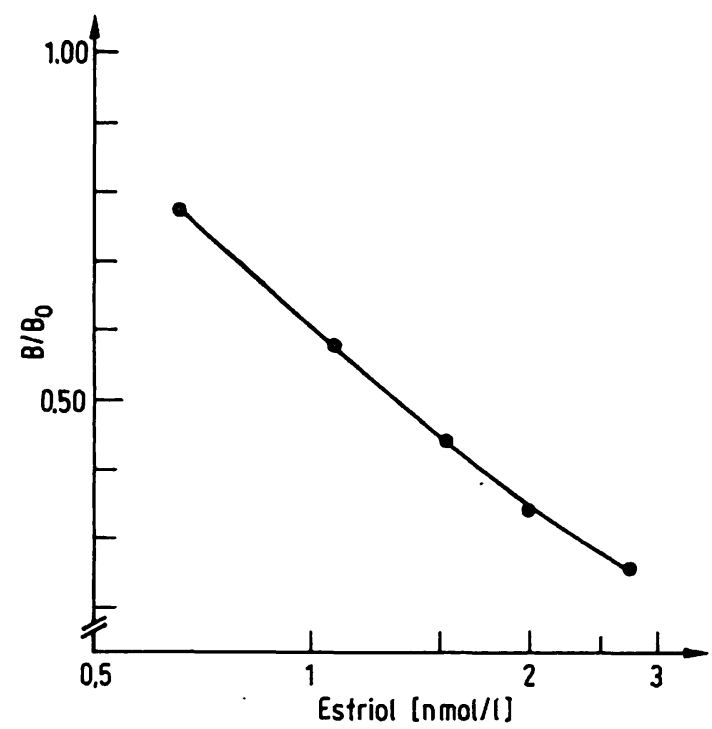

Fig. 1. Representative example of a standard curve, obtained with the estriol standard supplied by the manufacturer.

together with the original samples. All samples were analyzed in duplicate. Table 3 shows the results of these recovery studies. Mean analytic recovery was found to be $102 \%$.

\section{Antiserum affinity for different estrogens}

To check the antiserum affinity for the three most important estrogens, estrone, estradiol and estriol, we prepared standard solutions for each of the estrogens, with concentrations similar to those for a normal standard curve. Standard curves, obtained with the three different estrogens are visualized in figure 2.

\section{Hydrolysis with Helix pomatia extract}

The Helix pomatia extract contains sulphatase and glucuronidase. We checked the hydrolyzing capacities of the extract by adding small volumes of six different stock solutions, each containing a different estrogen conjugate to a human serum pool. Samples containing

Tab. 3. Results of recovery studies with unconjugated estriol.

\begin{tabular}{lllll}
\hline $\begin{array}{l}\text { Sample } \\
\text { no. }\end{array}$ & Initial value & $\begin{array}{l}\text { Added } \\
\text { Estriol }\end{array}$ & Final value & $\begin{array}{l}\text { Recovery } \\
\text { Ref added } \\
\text { estriol }\end{array}$ \\
& (nmol/1) & (nmol/1) & (nmol/1) & (\%) \\
\hline 1 & 840 & 415 & 1370 & 28 \\
1 & 840 & 830 & 1690 & \\
1 & 840 & 1380 & 2470 & 1. \\
2 & 1580 & 830 & 2450 & 160 \\
2 & 1580 & 1380 & 3020 & 104 \\
3 & 1920 & 830 & 2670 & 90 \\
3 & 1920 & 1380 & 3600 & 96 \\
4 & 1265 & 1380 & 2750 & 107 \\
5 & 1275 & 830 & 1770 & 59 \\
6 & 1200 & 830 & 1940 & 90 \\
7 & 1740 & 830 & 2550 & 98 \\
8 & 1510 & 1380 & 3070 & 113 \\
9 & 1170 & 830 & 1820 & 79 \\
10 & 1250 & 1380 & 2840 & 115 \\
11 & 1280 & 1380 & 2800 & 110 \\
12 & 1550 & 1380 & 3070 & 110 \\
\hline
\end{tabular}

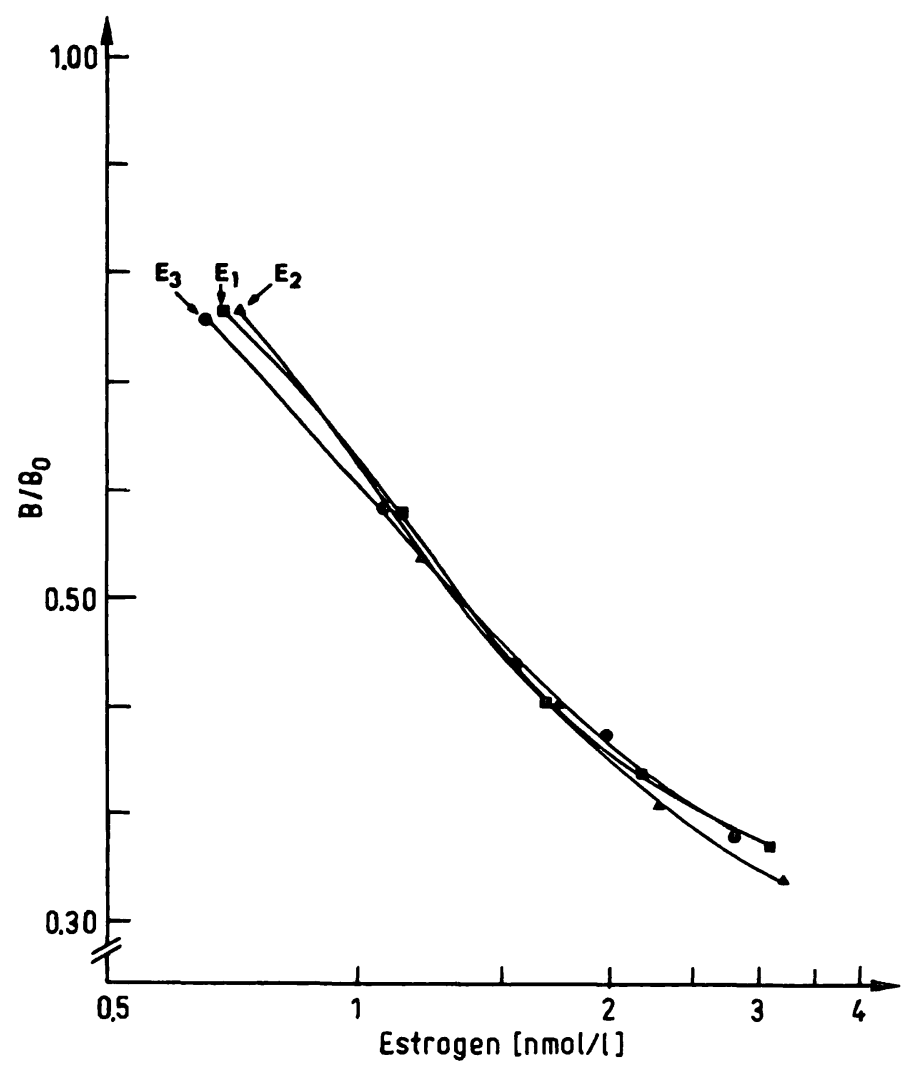

Fig. 2. Standard curves obtained with three different estrogens. For abbreviations: see table 1 .

extra conjugates were then analyzed together with the original pool-serum for their estrogen concentration according to the normal procedure. In this experiment we used only estrone and estriol conjugates, since estradiol in serum is predominantly in the unconjugated form. The recoveries that were found for the different conjugates are shown in table 4.

Tab. 4. Results of recovery studies with different estrogen conjugates. For abbreviations: see table 1.

\begin{tabular}{|c|c|c|c|c|}
\hline $\begin{array}{l}\text { Added } \\
\text { conjugate }\end{array}$ & $\begin{array}{l}\text { Initial } \\
\text { concentra- } \\
\text { tion } \\
(\mathrm{nmol} / \mathrm{l})\end{array}$ & $\begin{array}{l}\text { Added } \\
\text { concentra- } \\
\text { tion } \\
(\mathrm{nmol} / \mathrm{l})\end{array}$ & $\begin{array}{l}\text { Final } \\
\text { concentra- } \\
\text { tion } \\
(\mathrm{nmol} / \mathrm{l})\end{array}$ & $\begin{array}{l}\text { Recovery } \\
\text { of added } \\
\text { estrogen } \\
(\%)\end{array}$ \\
\hline$E_{3}-3 G$ & $\begin{array}{l}1220 \\
1220 \\
1220\end{array}$ & $\begin{array}{l}3200 \\
4980 \\
6730\end{array}$ & $\begin{array}{l}4240 \\
5760 \\
7720\end{array}$ & $\begin{array}{l}94 \\
91 \\
97\end{array}$ \\
\hline$E_{3}-3 S$ & $\begin{array}{l}1220 \\
1220 \\
1220\end{array}$ & $\begin{array}{l}4490 \\
6990 \\
9430\end{array}$ & $\begin{array}{l}4610 \\
5760 \\
7420\end{array}$ & $\begin{array}{l}76 \\
65 \\
66\end{array}$ \\
\hline $\mathrm{E}_{\boldsymbol{3}}-17 \mathrm{G}$ & $\begin{array}{l}1220 \\
1220 \\
1220\end{array}$ & $\begin{array}{l}2510 \\
3900 \\
5250\end{array}$ & $\begin{array}{l}3400 \\
4900 \\
6520\end{array}$ & $\begin{array}{r}87 \\
94 \\
101\end{array}$ \\
\hline$E_{3}-16 G$ & $\begin{array}{l}1220 \\
1220 \\
1220\end{array}$ & $\begin{array}{r}5570 \\
8660 \\
11700\end{array}$ & $\begin{array}{r}6340 \\
9570 \\
12220\end{array}$ & $\begin{array}{l}92 \\
96 \\
94\end{array}$ \\
\hline$E_{1}-3 S$ & $\begin{array}{l}1220 \\
.1220 \\
1220\end{array}$ & $\begin{array}{l}4250 \\
6610 \\
8920\end{array}$ & $\begin{array}{r}6560 \\
8300 \\
10370\end{array}$ & $\begin{array}{l}126 \\
107 \\
103\end{array}$ \\
\hline$E_{1}-3 G$ & $\begin{array}{l}1220 \\
1220 \\
1220\end{array}$ & $\begin{array}{r}4870 \\
7580 \\
10240\end{array}$ & $\begin{array}{r}5890 \\
8490 \\
10240\end{array}$ & $\begin{array}{l}96 \\
96 \\
88\end{array}$ \\
\hline
\end{tabular}




\section{Preliminary clinical studies}

The preliminary clinical studies included 14 pregnant women. Gestational lengths at the beginning of the studies ranged from 23 to 28 weeks. One pregnancy was complicated by severe hypertension, another one by severe maternal diabetes. The other 12 pregnancies proceeded without serious complications. At 9.00 a. m. during each 24 hour urine collection a blood sample was taken for total estrogen analysis. This procedure was continued for at least 5 weeks during each pregnancy.
We calculated Spearman rank correlation coefficients to demonstrate the presence or absence of a significant trend in total estrogen value with increasing gestational length. In each case the gestational length was taken as one variable and either the total 24 hour urine estrogen excretion, or urinary estrogen/creatinine ratio or serum total estrogen concentration as the other. Table 5 summarized the results of these calculations for the 14 pregnancies.

Figures 3,4 and 5 show some representative examples of the fluctuations of estrogen values during pregnancy.

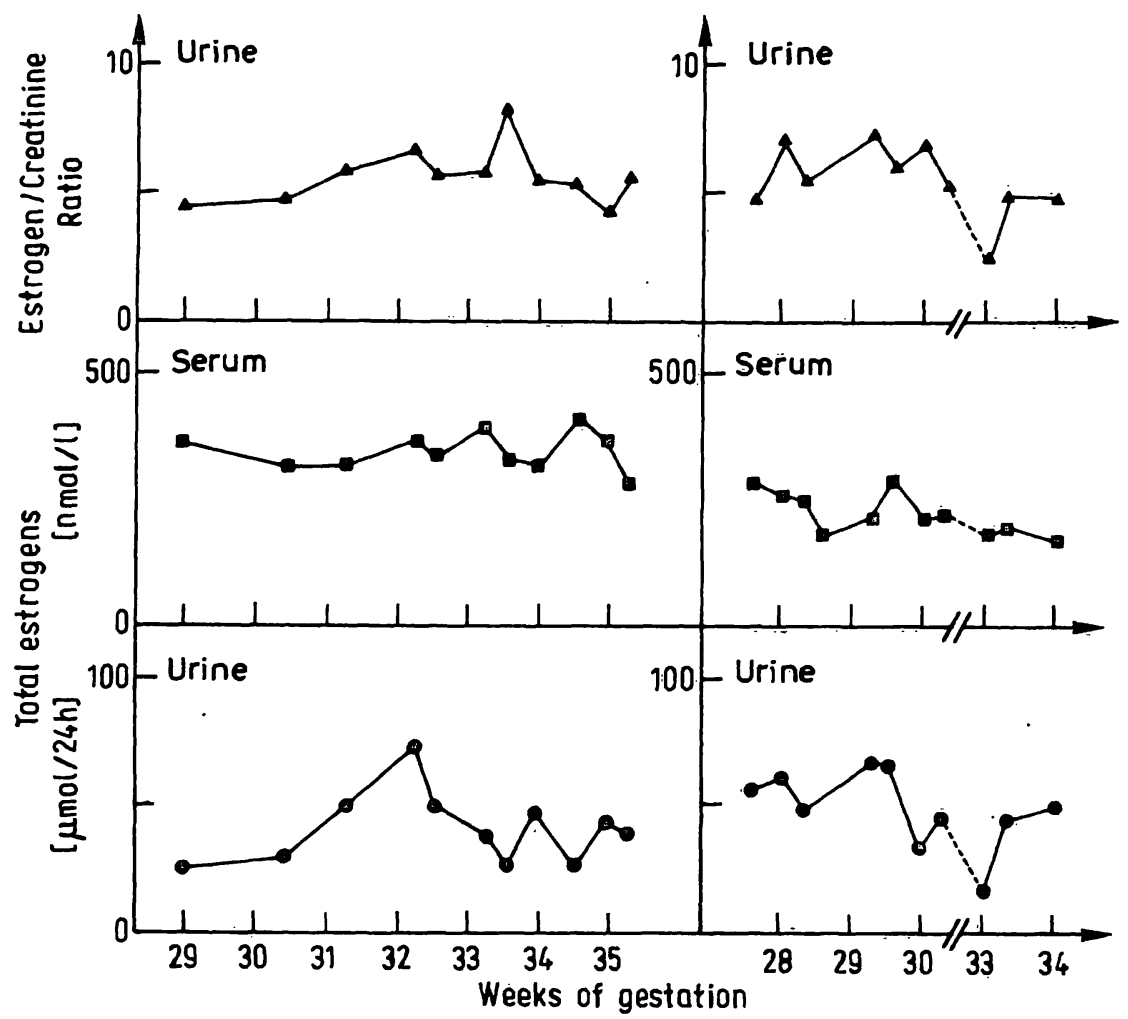

Fig. 3. Examples of estrogen values during complicated pregnancies. Left: values for patient no. 2, the diabetic woman: Right: values for patient no. 4 , the hypertensive patient. Estrogen/creatinine ratios calculated from estrogens $(\mu \mathrm{mol} / \mathrm{l})$ and creatinine $(\mathrm{mmol} / \mathrm{l})$.

Tab. 5. Spearman rank correlation coefficients $\left(\mathbf{R}_{\mathrm{s}}\right)$ for 14 pregnancies, with the gestational length as one variable and either urine or serum estrogen value as the second variable.

\begin{tabular}{|c|c|c|c|c|c|c|c|}
\hline \multirow[t]{2}{*}{ Patient no. } & \multirow[t]{2}{*}{$\begin{array}{l}\text { Test period } \\
\text { (weeks) }\end{array}$} & \multicolumn{2}{|c|}{$\begin{array}{l}\text { Urine total estrogens/ } 24 \mathrm{~h} \\
\text { vs. gestational length }\end{array}$} & \multicolumn{2}{|c|}{$\begin{array}{l}\text { Urine } \mathrm{E} / \mathrm{C} \text { ratio } \\
\text { vs. gestational length }\end{array}$} & \multicolumn{2}{|c|}{$\begin{array}{l}\text { Serum total estrogens } \\
\text { vs. gestational length }\end{array}$} \\
\hline & & $\mathrm{R}_{\mathrm{s}}{ }^{*}$ & $\begin{array}{l}\text { Signifi- } \\
\text { cance** }\end{array}$ & $\mathbf{R}_{\mathbf{s}}^{*}$ & $\begin{array}{l}\text { Signifi- } \\
\text { cance** }\end{array}$ & $\mathrm{R}_{\mathrm{s}}^{*}$ & Significance** \\
\hline $\begin{array}{r}1 \\
2 \\
3 \\
4 \\
5 \\
6 \\
7 \\
8 \\
9 \\
10 \\
11 \\
12 \\
13 \\
14\end{array}$ & $\begin{array}{l}31-36 \\
29-35 \\
31-38 \\
27-33 \\
30-37 \\
29-34 \\
28-37 \\
23-30 \\
30-39 \\
30-35 \\
31-39 \\
31-38 \\
28-35 \\
30-39\end{array}$ & $\begin{array}{rr}0.231 & (14) \\
0.051 & (12) \\
0.293 & (15) \\
-0.524 & (10) \\
-0.104 & (18) \\
0.660 & (14) \\
0.477 & (20) \\
0.467 & (17) \\
0.682 & (21) \\
0.2 & (11) \\
0.329 & (18) \\
0.893(7) \\
0.514 & (18) \\
0.374 & (26)\end{array}$ & $\begin{array}{l}\text { NS } \\
\text { NS } \\
\text { NS } \\
\text { NS } \\
\text { NS } \\
\text { S } \\
\text { S } \quad \cdots \\
\text { S } \\
\text { S } \\
\text { NS } \\
\text { NS } \\
\text { S } \\
\text { S } \\
\text { S }\end{array}$ & $\begin{array}{rr}-0.042 & (14) \\
0.168 & (11) \\
0.577 & (15) \\
-0.479 & (10) \\
-0.318 & (18) \\
0.785(14) \\
0.242(20) \\
0.851(17) \\
0.713(21) \\
0.882(11) \\
0.463(18) \\
0.955(7) \\
0.240(18) \\
0.662(27)\end{array}$ & $\begin{array}{l}\text { NS } \\
\text { NS } \\
\text { S } \\
\text { NS } \\
\text { NS } \\
\text { S } \\
\text { NS } \\
\text { S } \\
S \\
S \\
S \\
S \\
\text { NS } \\
\text { S }\end{array}$ & $\begin{array}{r}0.282(11) \\
-0.014(11) \\
0.734(12) \\
-0.634(11) \\
0.407(18) \\
0.688(14) \\
0.067(18) \\
0.872(18) \\
0.828(21) \\
0.035(12) \\
-0.327(19) \\
0.714(7) \\
0.895(18) \\
0.918(27)\end{array}$ & $\begin{array}{l}\text { NS } \\
\text { NS } \\
\text { S } \\
\text { S } \\
\text { S } \\
\text { S } \\
\text { NS } \\
\text { S } \\
\dot{S} \\
\text { NS } \\
\text { NS } \\
\text { S } \\
\text { S } \\
\text { S }\end{array}$ \\
\hline
\end{tabular}

* In parentheses: number of observations within the test period.

** S: significant at $\mathrm{p}<0.05$ level. NS: not significant at $\mathrm{p}<0.05$ level. $\mathrm{E} / \mathrm{C}=$ Estrogen/creatinine ratio 


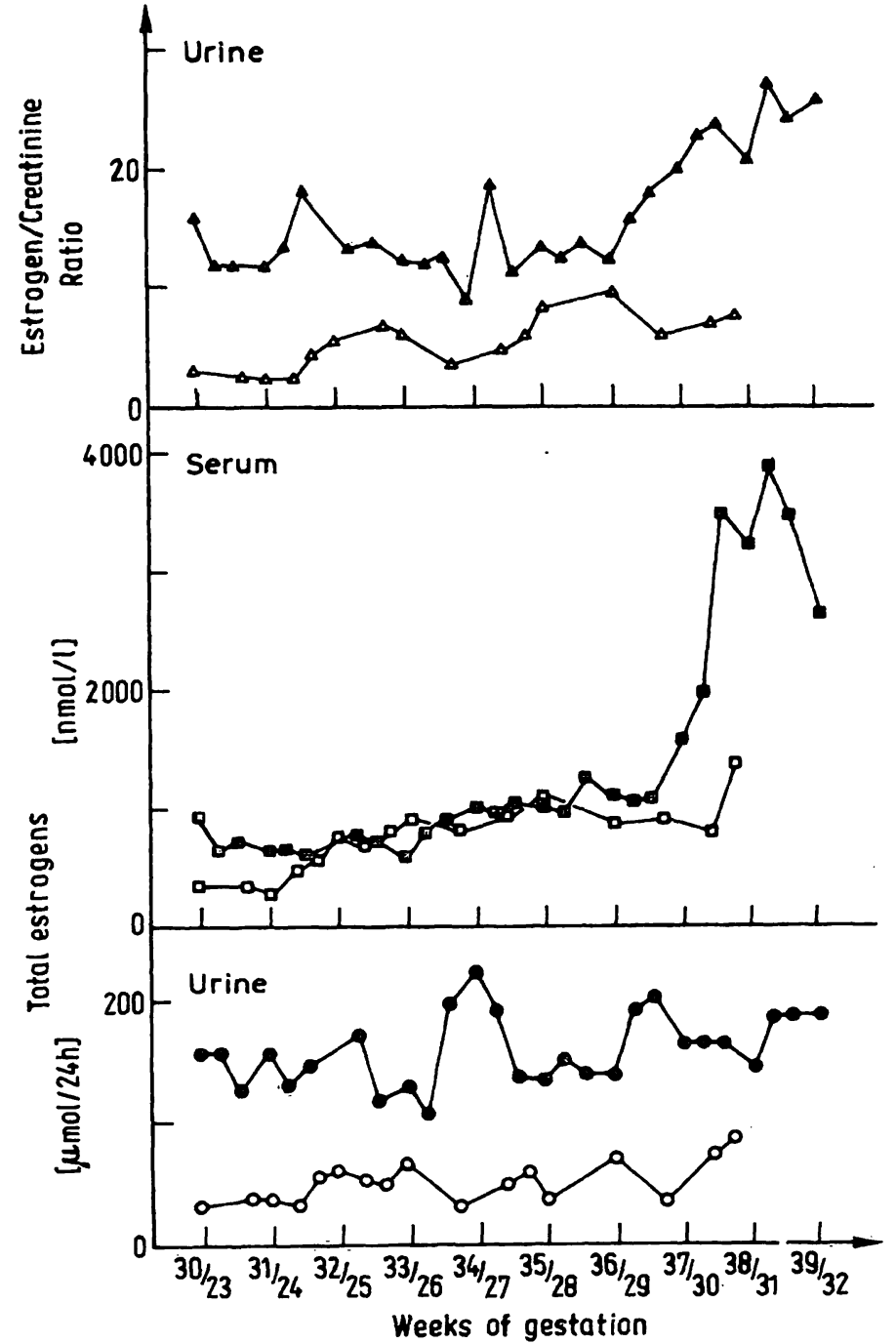

Fig. 4. Fluctuations in estrogen values during pregnancy. Closed symbols: patient no. 14 . Open symbols: patient no. 8. Numbers left of the stroke: gestational length for patient no. 14. Numbers right of the stroke: gestational length for patient no. 8. Estrogen/creatinine ratios calculated from estrogens $(\mu \mathrm{mol} / \mathrm{l})$ and creatinine $(\mathrm{mmol} / \mathrm{l})$.

The left half of figure 3 illustrates the estrogen values from a 34-year-old gravida 3 para 2 with severe insulin dependent diabetes (patient no. 2). Estrogen values in serum and urine were low, but echoscopic examination indicated a normal growing fetus. At 35 weeks of gestation, a live, premature infant, birthweight $2180 \mathrm{~g}$, was delivered by cesarian section. The right half of figure 3 shows the estrogen values from a 30-year-old gravida 2 para 0 with severe hypertension (patient no. 4). Again, estrogen values in serum and urine were low. In this case only the serum estrogen concentrations showed a significantly falling trend. On echoscopic examination fetal growth was found to be impaired and at 35 weeks of gestation a dead fetus, weighing $800 \mathrm{~g}$ was delivered. On microscopic examination approximately $20 \%$ of the placenta appeared to be infarcted. Figure 4 shows the course of estrogen values in patients no. 14 and 8 , who were hospitalized for threatened immature labor and moderate pregnancy induced hypertension, respectively.

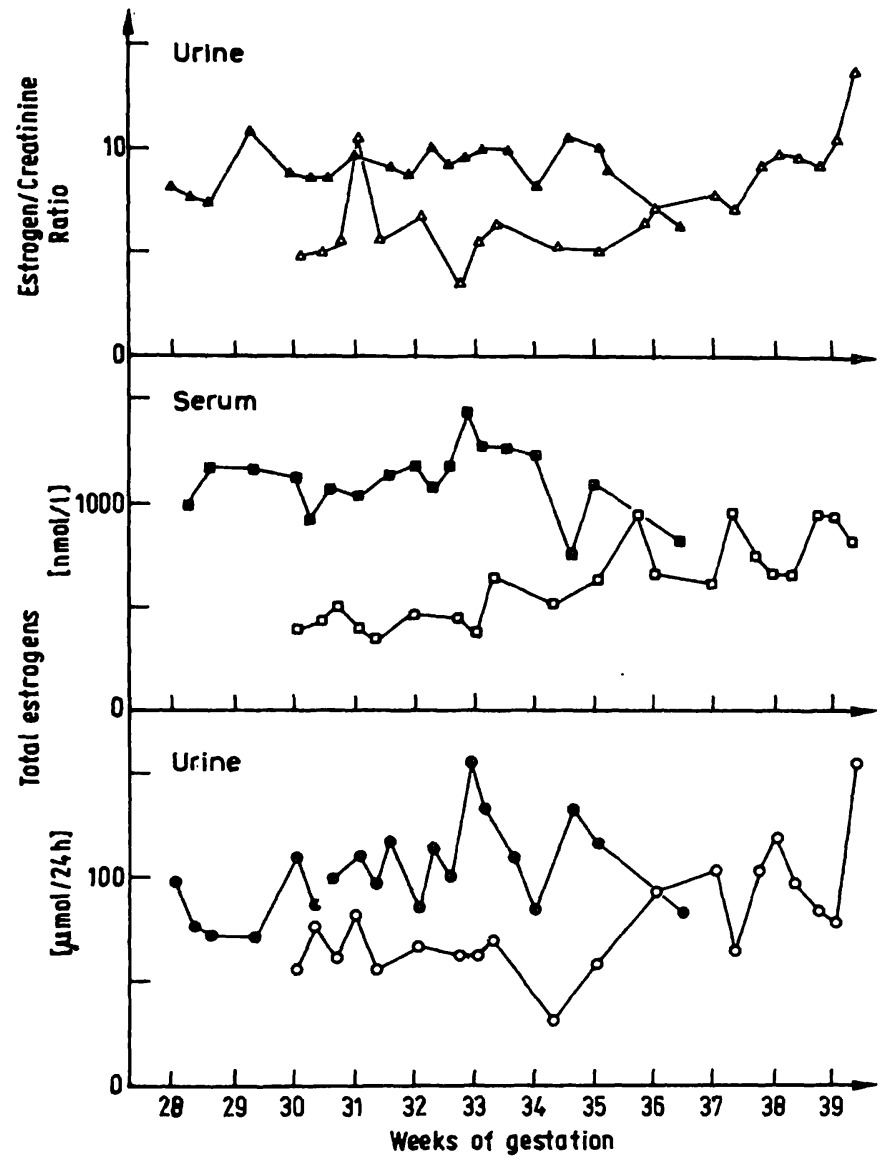

Fig. 5. Fluctuations in estrogen values during normal pregnancy. Closed symbols: patient no. 7. Open symbols: patient no. 9. Estrogen/creatinine ratios calculated from estrogens $(\mu \mathrm{mol} / \mathrm{l})$ and creatinine $(\mathrm{mmol} / \mathrm{l})$.

Both pregnancies continued without further complications and both patients were delivered of healthy infants. Finally, figure 5 illustrates two normal pregnancies (patients no. 7 and 9), resulting in full term, normal-birthweight infants.

\section{Discussion}

We have evaluated a new commercially available enzymeimmuno-assay for determination of total estrogens in serum or plasma.

The precision studies performed in urine with our routine Auto-Analyzer method and in serum with the new assay, show that both methods have comparable within-run precisions, whereas the serum assay has a better day-to-day precision. The coefficients of variation we found for the serum assay are comparable with values reported in the literature for radio-immuno-assay procedures $(8,9)$.

The recovery of added estriol was good; mean analytical recovery for all experiments was found to be $102 \%$. One sample (no. 5 in table 3) showed a low recovery of $59 \%$. We have no explanation for this. 
The manufacturer of the enzyme-immuno-assay kit claims that the antiserum has equal affinity for estrone, estradiol and estriol. This is confirmed by our experiments with the standard solutions of each estrogen. The standard curves obtained with each estrogen were virtually equal.

Hydrolysis experiments were performed with estrogen conjugates that are found predominantly in serum. The results indicate that hydrolysis is virtually complete for all conjugates tested, except for estriol-3-sulphate, which shows a somewhat lower recovery. We have no explanation for this observation. A saline solution of the same conjugate was hydrolyzed completely.

The amounts of conjugates added to the serum pool were sufficient to produce final concentrations above the upper normal limit for full term pregnancies, as given by the manufacturer (about $3500 \mathrm{nmol} / \mathrm{l}$ ). Therefore, it can be concluded that the Helix pomatia extract hydrolyzes virtually all conjugated estrogens present in a serum sample.

It is of practical interest that the enzyme-immuno-assay procedure is quite laborious. In particular, centrifugation and washing procedures are time consuming when large series are analyzed. On the other hand, many manual procedures for urine total estrogen determinations are also laborious, because of extraction and washing procedures. With proper equipment we were able to analyze 30-40 samples in duplicate within one working day. Similar values have been reported for radio-immunoassay procedures (8). With an Auto-Analyzer, 100-125 samples can be analyzed within one day, but because of reagent preparation and starting up and calibration procedures the instrument has a lagtime of about $2 \frac{1}{2}$ hours, which makes it less suitable for small series. Moreover, the instrument is quite expensive (about 100,000 Dutch Guilders).

The total estrogen concentrations obtained with the enzyme-immuno-assay are not directly comparable with values obtained with commercially available radioimmuno-assay kits, since these measure mostly only one type of estrogen. In the work of Bosch et al. (4) the authors have compared the enzyme-immuno-assay with a radio-immuno-assay, using the same antibody. Both methods showed a good correlation.

Our first clinical results suggest that total estrogens in serum and in urine provide similar information with respect to fetoplacental function. We have not always found a significant rise in serum estrogens with increasing gestational length in normal pregnancies, but this applies to urine determinations as well. According to table 5 serum total estrogens and urine total estrogens showed a similar result $\left(R_{s}\right.$ significant ( $S$ ) or not significant (NS) at the $p<0.05$ level) in 10 out of 14 pregnancies. For serum total estrogens and urine estrogen/creatinine ratio the results were similar in 9 out of 14 pregnancies, while both urine values showed similar results in 9 out of 14 pregnancies.

Though the occurrence of diurnal variations of blood estrogens has been claimed $(10)$, others $(11,12)$ have not been able to demonstrate a significant diurnal rhythm. In our studies, diurnal variation is unlikely to have influenced the results, since all samples were taken at the same time of the day, i. e. 9.00 a. m.

A disadvantage of using urine samples is the difficulty of obtaining a reliable 24-hour collection. Though the estrogen/creatinine ratio can be used to circumvent this problem (13), it has been shown that clearances of estrogen and creatinine can vary independently in cases of complicated pregnancy (14). Because of this, and because of the results of this study, we feel that the enzyme-immuno-assay of total estrogens in serum can be considered an attractive alternative to the determination of total estrogens in urine for monitoring of the fetoplacental unit.

In contrast to methods for serum estrogen determinations that use radioactive tracers, no permit or special counting equipment is needed for the enzyme-immunoassay of serum total estrogens, which makes the method more widely applicable.

\section{References}

1. Gurpide, E., Giebenhain, M. E., Tseng, L. \& Kelly, W. G. (1971), Am. J. Obstet. Gynecol. 109, 897-906.

2. Mikhail, G., Wu, C. H., Ferin, M. \& Van de Wiele, R. L. (1970), Steroids 15, 333-352.

3. Wu, C. H. \& Lundy, L. E. (1971), Steroids $18,91-111$.

4. Bosch, A. M. G., Dijkhuizen, D. M., Schuurs, A. H. W. M. \& Van Weemen, B. K. (1978), Clin. Chim. Acta 89, 59-70.

5. Van Kessel, H., Seitzinger, R., Schreurs, J. \& Versteeg, M. (1969), Ned. T. Verlosk. 69, 81-90.

6. Ittrich, G. (1966), Acta Endocrinol 35, 34.

7. Kreutzer, H. J. H. \& Meulendijk, P. N. (1968), Clin. Chim. Acta 22, 481-489.

8. Craig, A. (1976), Clin. Chim. Acta 68, 277-286.

9. Powell, J. E. \& Stevens, V. C. (1973), Clin. Chem. 19, $210-$ 215.
10. Townsley, J. D., Dubin, N. H., Grannis, G. F., Gartman, L. J. \& Crystle, C. D. (1973), J. Clin. Endocrinol. Metab. 36, 289-295.

11. Masson, G. M. \& Wilson, G. R. (1972), J. Endocrinol. 54, 245-250.

12. Lindberg, B. S., Johansson, E. D. B. \& Nilsson, B. A. (1974), Acta Obstet. Gynaecol. Scand. (Suppl.) 32, 21-36.

13. Dickey, R. P., Besch, P. K., Vorys, N. \& Ullery, J. C. (1966), Am. J. Obstet. Gynecol. 94, 591-594.

14. Carrington, E. R., Oesterling, M. J. \& Adams, F. M. (1970), Am. J. Obstet. Gynecol. 106, 1131-1143.

Drs. A. Lanser

R. K. Żiekenhuis

Houttuinen 10

NL 3300 ÁL Dordrecht 